\title{
Analysis of Odor Compounds in Feces of Mice that Were Exposed to Various Stresses during Breeding
}

\author{
Kenji SAKUMA $^{1,2)}$, Susumu HAYASHI ${ }^{2)}$, Yoshiyuki YASAKA ${ }^{3)}$, Hiroto NISHIJIMA ${ }^{3)}$, \\ Hisakage FUNABASHI ${ }^{1,4)}$, Masayoshi HAYASHI ${ }^{2)}$, Hideaki MATSUOKA ${ }^{1)}$, and Mikako SAITO ${ }^{1)}$ \\ 1) Department of Biotechnology and Life Science, Tokyo University of Agriculture and Technology, 2-24-16 Naka- \\ cho, Koganei, Tokyo 184-8588, Japan \\ ${ }^{2)}$ Oriental Giken Inc., 2-9 Kanda Nishiki-cho, Chiyoda-ku, Tokyo 101-0054, Japan \\ 3) Oita Laboratory, Sumika Chemical Analysis Service, Ltd., 2200 Tsurusaki, Oita-shi, Oita 870-0106, Japan \\ 4) Present address: Institute for Sustainable Science and Development, Hiroshima University, 2-313 Kagamiyama, \\ Higashihiroshima, Hiroshima 739-8527, Japan
}

\begin{abstract}
In order to provide healthy experimental animals, it is important to find and remove animals that have been accidentally exposed to various stresses during breeding. This study focuses mouse health-care management. Here we used human olfaction and gas chromatography-mass spectrometry to assess odor intensity and determine the concentrations of odor components. The feces were collected from mice that were exposed to 4 different stresses (no bedding chips, shaking, fasting, and movement restriction). These stresses caused a change in odor intensity as assessed by 6 panelists. Seventeen components were identified as dominant components in the odor that was emitted from feces. The concentration of each compound was converted to relative values versus its odor threshold levels in order to select ones effective for the quality of the odor. As a result, 12 selected components were found to be a useful set for the recognition of mice bred under different stress conditions. The present results may provide useful information for the development of standard fecal odor materials that may be used for the training of mouse care personnel.
\end{abstract}

Key words: mouse care management, mouse feces, standard fecal odor material, stress specific odor

\section{Introduction}

In recent years, the contribution of laboratory animals to life science research has continued to grow rapidly, placing ever greater importance on the quality of the animals being produced for this research [8]. As a consequence of advances in genetic engineering and reproductive biology techniques, it is possible to design and obtain specified strains of laboratory animals. Generation and use of such strains requires that the quality of each animal be strictly controlled to ensure the accuracy of experimental results. The exposure of animals to stress during breeding and maintenance can affect their physiological condition $[7,9]$. Ascertaining whether the experimental animals have been subjected to undue stress is clearly important prior to starting critical experiments.

The reduction or elimination of stress from the general environment is a desirable goal in animal welfare [5]. Achievement of this goal requires a reliable means of identifying animals that have been subjected unintentionally to stress. A reliable stress indicator must be able to reflect the physiological state of the animal but should not impose any new stress on the animal. For example, serological analyses of blood components are well-es-

(Received 18 August 2012 / Accepted 1 November 2012)

Address corresponding: M. Saito, Department of Biotechnology and Life Science, Tokyo University of Agriculture and Technology, 2-24-16 Nakacho, Koganei, Tokyo 184-8588, Japan

(C)2013 Japanese Association for Laboratory Animal Science 
tablished methods; however, collection of blood is unsuitable for a daily screen, as it would not be feasible to perform on large numbers of mice and would also be a source of stress to the animals $[2,15]$. Recently, a noninvasive approach was described using volatile organic compounds in mouse urine; the levels of these compounds were compared statistically in an attempt to correlate them with the state of stress of the mice [14]. However, this approach is too labor intensive and timeconsuming in terms of the instrumental analyses and bioassays to be suitable for routine screening of large numbers of mice. Another possibility might be to make use of feces: clinical analyses of the physiological state of patients are often performed through evaluation of intestinal bacteria in feces [3]. Although analysis of intestinal microbiota is unlikely to be feasible as a daily screen in laboratory mice, it may be feasible to exploit the odor compounds in the feces to construct an odor testing scheme. Feces contain the waste products of digestion along with intestinal microbiota [11]; the metabolic processes of the microbiota are responsible for the production of the odor components that determine the odor of the feces. Various low molecular weight compounds, such as volatile fatty acids, indoles, and phenols, are produced by the intestinal bacteria and are present in feces [4]. The odor of feces therefore reflects its chemical composition, and possibly also the intestinal environment of the animal. It is known that aging and stress can cause changes to the intestinal microbiota [1, $10,12]$. From daily contact with the animals, we noticed that fecal odors did change occasionally. Therefore, it is possible that changes in the odor of the feces might reflect changes in the state of stress in the mice.

In order to use odor as a screen of stress in the animals, it will be essential to establish reliable guidelines that can be applied easily and consistently. The human nose has been shown to be sensitive to variations in many odors $[6,13]$. Most people possess the required level of olfactory sensitivity for this type of test, and applying this screen should not add greatly to the workload of the staff running the animal breeding facility. Therefore, in theory, this approach is feasible. Here, we applied various stresses to mice in breeding cages and analyzed the odor components in the feces. The results of these analyses suggest that it should be possible to construct a simple stress screen based on fecal odors.

\section{Materials and Methods}

\section{Mice and breeding conditions}

Female C57BL/6J mice (CLEA Japan, Inc., Tokyo, Japan) were kept at $25 \pm 5^{\circ} \mathrm{C}$ in a specific pathogen free (SPF) room that satisfied the cleanliness criteria for class 7 of ISO 14644-1. The diet used in this study was MF purchased from Oriental Yeast Co., Ltd., (Tokyo, Japan). This diet is a solid pellet for general purposes. It contains $23.1 \mathrm{~g}$ of crude protein, $5.1 \mathrm{~g}$ of rough lipids, $5.8 \mathrm{~g}$ of crude ash, $2.8 \mathrm{~g}$ of crude fiber, $55.3 \mathrm{~g}$ of nitrogen-free extracts, and $7.9 \mathrm{~g}$ of moisture. In terms of calories, it contains $359 \mathrm{kcal}$ per $100 \mathrm{~g}$ diet.

Eighteen 20-week-old mice of similar size were selected for the odor analysis, of which 6 mice were used as a control group and 4 groups of 3 mice were exposed to the different stress conditions. Care and use of the mice were in accordance with the requirements of the Guide for the Care and Use of Laboratory Animals established by Tokyo University of Agriculture and Technology, Japan.

\section{Stress application}

The stress exposure experiments were performed with mice kept individually in cages using the following conditions. Control mice were placed in cages that contained about $100 \mathrm{~g}$ of wooden bedding chips and were allowed free access to food and water. For the no bedding chips stress experiment, mice were kept for $60 \mathrm{~h}$ in cages without bedding chips. For the shaking stress experiment, the cage was placed on a reciprocal shaking machine $(100 \mathrm{rpm})$ for $60 \mathrm{~h}$. For the fasting stress experiment, mice were allowed access only to water for $24 \mathrm{~h}$ and then to both food and water for the next $36 \mathrm{~h}$. For the movement restriction stress experiment, the mice were placed in narrow transparent plastic boxes $(15 \times 15 \mathrm{~cm})$ in the cages.

\section{Collection of feces}

At the time of collection of feces, we picked up a mouse and pressed its abdomen softly to induce defecation. Then we collected fecal pellets directly from the anus. This method was found convenient for the collection of feces without contamination with urine. Immediately after collection, the feces were weighed, put in airtight vials, and cooled at $4^{\circ} \mathrm{C}$. The vials were maintained at $4^{\circ} \mathrm{C}$ until the $\mathrm{GC} / \mathrm{MS}$ analysis. 
Table 1. Olfactory evaluation of odors emitted from feces

\begin{tabular}{|c|c|c|}
\hline Breeding conditions & $\begin{array}{c}\text { Odor intensity } \\
(m e a n \pm S E M, \text { for } n=6)\end{array}$ & Odor properties \\
\hline Control & $2.3 \pm 0.1$ & $\begin{array}{l}\text { Slight smell } \\
\text { Like silage and milk }\end{array}$ \\
\hline No bedding chips stress & $3.8 \pm 0.1$ & $\begin{array}{l}\text { Intense unpleasant odor } \\
\text { Like condensed milk }\end{array}$ \\
\hline Shaking stress & $3.2 \pm 0.2$ & $\begin{array}{l}\text { Intense unpleasant odor } \\
\text { Like condensed milk } \\
\text { Like the aroma of roasting beans }\end{array}$ \\
\hline Fasting stress & $1.8 \pm 0.9$ & $\begin{array}{l}\text { Sulfurous smell } \\
\text { Like condensed milk } \\
\text { Like the aroma of roasting beans }\end{array}$ \\
\hline Movement restriction stress & $3.8 \pm 0.1$ & $\begin{array}{l}\text { Intense unpleasant odor } \\
\text { Like condensed milk }\end{array}$ \\
\hline
\end{tabular}

\section{Evaluation of odor by human olfaction}

The odor of feces was examined by smelling by 6 panelists ( 3 men and 3 women) based on a method developed for flavor profiling [16]. In this method, odor is described in terms of characteristic notes, and the intensity of the odor is assessed using following scale: $0=$ not detected, 1=recognizable (equal or slightly higher than threshold level), $2=$ weak, $3=$ moderate, $4=$ strong. Total intensity of odor was determined by averaging the results of screening of fecal pellets from animals in the same experimental group.

\section{Quantitative analysis of odor components}

Approximately $20 \mathrm{mg}$ of feces were transferred to a vial for a head-space analysis. The feces were heated at $40^{\circ} \mathrm{C}$ for $1 \mathrm{~h}$, and the volatile components from the feces were separated and analyzed by microscale purge and trap gas chromatography-mass spectrometry (MPT-GC/ MS) (MPT, Entech Instruments, Inc., Simi Valley, CA, USA; GC/MS, Agilent Technologies, Inc., Santa Clara, CA, USA). To identify the peaks detected, we referred to the database of 275,000 substances in the WILEY/ NIH library. The concentration of each compound was estimated by the standard method based on the assumption that the sensitivity of the apparatus to each component should be equal to that to toluene. Thus the concentrations of respective components (vol ppb) were determined from their peak areas compared with that of the internal toluene standard.

\section{Statistical analysis by ANOVA}

An analysis of variance (ANOVA) was performed for the results of human olfaction. The parameters for ANO-
VA were as follows: number of groups $=5$ (the control condition and 4 stress conditions), degrees of freedom between groups $=4$, and degrees of freedom within groups $=25[(\Sigma$ (scoring data by 6 panelists -1$)$ of every group].

ANOVA was also performed for each of the compounds assigned by GC/MS. The parameters for ANOVA were defined as follows: number of groups $=5$ (the control condition and 4 stress conditions), degrees of freedom between groups $=4$, and degrees of freedom within groups $=13[\Sigma$ (measured data of 6 or 3 samples -1$)$ of every group].

In this study, the criterion for statistical significance was a probability $(P)$ of less than 0.05 .

\section{Qualitative analysis of stress-specific compounds}

The concentration of each compound was compared with its olfactory threshold level (TL). The intensity of odor of each component was assessed using following scale: $0=[<\mathrm{TL}], 1=[\mathrm{TL} \leq,<3 \times \mathrm{TL}], 2=[3 \times \mathrm{TL} \leq,<10 \times \mathrm{TL}]$, $3=[10 \times \mathrm{TL} \leq,<30 \times \mathrm{TL}], 4=[30 \times \mathrm{TL} \leq, \quad<100 \times \mathrm{TL}]$, $5=[100 \times \mathrm{TL} \leq,<300 \times \mathrm{TL}], 6=[300 \times \mathrm{TL} \leq]$.

\section{Results and Discussion}

\section{Odor quality assessed by human olfaction}

The total intensity of odor and the odor properties of the feces are given in Table 1. Notably, odor intensity was consistently increased by exposure to stress except fasting stress. ANOVA revealed that the differences between the following pairs of results were statistically significant: $\mathrm{C}$ and $\mathrm{N}, \mathrm{C}$ and $\mathrm{M}, \mathrm{F}$ and $\mathrm{N}$, and $\mathrm{F}$ and $\mathrm{M}$, where $\mathrm{C}, \mathrm{N}, \mathrm{M}$, and $\mathrm{F}$ are the control, no bedding chips stress, movement 
Table 2. Structural formulas and olfactory thresholds of 17 dominant compounds detected in mouse feces

\begin{tabular}{|c|c|c|c|}
\hline Compounds & Structural formula & MW & $\begin{array}{l}\text { Olfactory threshold } \\
(\text { vol ppb) }\end{array}$ \\
\hline Acetaldehyde & & 86 & 1.5 \\
\hline Hexanal & & 100 & 0.28 \\
\hline Octanal & & 128 & 0.01 \\
\hline Nonanal & & 142 & 0.34 \\
\hline 3-methylbutanal & & 86 & 0.1 \\
\hline 2-methylbutanal & & 86 & 0.18 \\
\hline Heptanal & & 114 & 0.18 \\
\hline Decanal & & 156 & 0.4 \\
\hline Pentanal & & 86 & 0.41 \\
\hline Isobutanal & & 72 & 0.35 \\
\hline Butanol & & 74 & 38 \\
\hline Dimethyl disulfide & & 94 & 2.2 \\
\hline Dimethyl sulfide & & 62 & 3 \\
\hline Trimethylamine & & 59 & 0.032 \\
\hline 2,3-butanedione & & 86 & 0.05 \\
\hline Ethyl butyrate & & 116 & 0.04 \\
\hline Isobutyric acid & & 88 & 1.5 \\
\hline
\end{tabular}

restriction stress, and fasting stress, respectively.

In parallel with the increase in total intensity of odor, unpleasantness of odor seemed to have been increased by stress exposure except fasting stress.

\section{Concentrations of dominant odor compounds determined by $M P T-G C / M S$}

From the compounds identified by MPT-GC/MS, 17 compounds (listed in Table 2) were selected according to the order of odor sensing threshold levels, and their concentrations were determined. These compounds included 10 aldehydes, 2 sulfides, and a single alcohol, amine, ketone, ester, and fatty acid. The concentration of acetaldehyde was highest under every condition and ranged from 3.7 to $26.3 \mathrm{vol} \mathrm{ppb}$ (Table 3 ). This is probably the result of production from pyruvates via pyruvate decarboxylase in bacteria under anaerobic conditions. The second most common component was trimethylamine detected under the no bedding chips and fasting stresses. This compound is well known to cause a pun- gent bad smell. However, the odor intensities of samples under the no bedding chips and fasting stresses were quite different, as described above (Table 1). Therefore, the odor of feces was not solely determined by the high concentration of a compound.

The concentrations of the other compounds were lower; 10 compounds were present at concentrations of less than $2 \mathrm{vol} \mathrm{ppb}$. These included isobutyric acid and dimethyl sulfide, which are also pungent compounds. Since the human nose is highly sensitive to bad odors even at low concentrations, it should be necessary to consider the contribution of these compounds if their odor threshold levels are low.

\section{Statistical analysis of the influence of stress}

ANOVA was performed with the analytical results of each compound listed in Table 2. As depicted in Table 3 , there were 6 samples for the control condition but only 3 for each stress condition. Moreover, the variation was quite large in many compounds. Under these conditions, 
Table 3. Dominant odor compounds emitted from feces of mice bred under various stress conditions

\begin{tabular}{|c|c|c|c|c|c|c|c|c|c|c|}
\hline \multirow{2}{*}{ Compounds } & \multicolumn{2}{|c|}{ Control } & \multicolumn{2}{|c|}{$\begin{array}{l}\text { No bedding } \\
\text { chips stress }\end{array}$} & \multicolumn{2}{|c|}{ Shaking stress } & \multicolumn{2}{|c|}{ Fasting stress } & \multicolumn{2}{|c|}{$\begin{array}{c}\text { Movement } \\
\text { restriction stress }\end{array}$} \\
\hline & Mean & $\begin{array}{c}(\mathrm{SEM} \\
\text { for } n=6)\end{array}$ & Mean & $\begin{array}{c}(\mathrm{SEM} \\
\text { for } n=3)\end{array}$ & Mean & $\begin{array}{c}(\mathrm{SEM} \\
\text { for } n=3)\end{array}$ & Mean & $\begin{array}{c}(\mathrm{SEM} \\
\text { for } n=3)\end{array}$ & Mean & $\begin{array}{c}(\mathrm{SEM} \\
\text { for } n=3)\end{array}$ \\
\hline Acetaldehyde & $14.9^{a)}$ & $(3.8)$ & 26.3 & $(8.4)$ & 16.8 & $(6.4)$ & 23.7 & $(7.8)$ & 3.7 & $(0.6)$ \\
\hline Hexanal & 0.2 & $(0.1)$ & 0.6 & $(0.1)$ & $\mathrm{nd}^{\mathrm{b})}$ & & 0.4 & $(0.1)$ & nd & \\
\hline Octanal & 0.5 & $(0.2)$ & 0.5 & $(0.2)$ & nd & & 0.7 & $(0.3)$ & 0.9 & $(0.6)$ \\
\hline Nonanal & 1.2 & $(0.6)$ & 1.0 & $(0.2)$ & nd & & 1.3 & $(0.7)$ & 2.4 & $(2.1)$ \\
\hline 3-Methylbutanal & 1.0 & $(0.4)$ & 4.9 & $(3.6)$ & 0.9 & $(0.3)$ & 0.8 & $(0.1)$ & 0.3 & $(0.0)$ \\
\hline 2-Methylbutanal & 0.4 & $(0.2)$ & 5.3 & $(5.3)$ & 0.2 & $(0.1)$ & 0.5 & $(0.1)$ & nd & \\
\hline Heptanal & nd & & nd & & nd & & nd & & 0.2 & $(0.1)$ \\
\hline Decanal & nd & & nd & & nd & & nd & & 1.0 & $(1.0)$ \\
\hline Pentanal & nd & & nd & & 0.2 & $(0.1)$ & nd & & nd & \\
\hline Isobutanal & 0.6 & $(0.1)$ & 2.0 & $(1.4)$ & 0.3 & $(0.1)$ & 0.6 & $(0.2)$ & 0.2 & $(0.1)$ \\
\hline Butanol & 1.5 & $(1.2)$ & 0.6 & $(0.4)$ & 3.3 & $(0.8)$ & 0.0 & $(0.0)$ & 1.9 & (1.9) \\
\hline Dimethyl disulfide & 0.1 & $(0.1)$ & 1.0 & $(1.0)$ & nd & & nd & & nd & \\
\hline Dimethyl sulfide & nd & & nd & & 0.4 & $(0.3)$ & nd & & 0.4 & $(0.4)$ \\
\hline Trimethylamine & nd & & 12.3 & (12.3) & nd & & 8.3 & $(2.7)$ & nd & \\
\hline 2,3-Butanedione & 7.1 & $(1.0)$ & 6.1 & $(3.1)$ & 6.9 & $(1.5)$ & 4.1 & $(0.8)$ & 2.6 & $(0.8)$ \\
\hline Ethyl butyrate & 0.4 & $(0.3)$ & 1.2 & $(1.2)$ & 0.1 & $(0.1)$ & nd & & nd & \\
\hline Isobutyric acid & nd & & 0.6 & $(0.6)$ & nd & & nd & & nd & \\
\hline
\end{tabular}

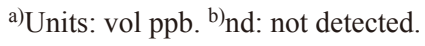

however, ANOVA revealed that statistically significant differences existed in the case of heptanal, hexanal, and pentanal.

Then we further analyzed these cases by a multiple comparison method based on the Tukey test. Consequently, we found that significant differences existed only between the following couples: heptanal ( $\mathrm{C}$ and $\mathrm{M}$, $\mathrm{N}$ and $\mathrm{M}, \mathrm{S}$ and $\mathrm{M}, \mathrm{F}$ and $\mathrm{M}$ ), hexanal (N and $\mathrm{S}, \mathrm{N}$ and $\mathrm{M}$ ), and pentanal (C and $\mathrm{S}, \mathrm{N}$ and $\mathrm{S}, \mathrm{F}$ and $\mathrm{S}, \mathrm{M}$ and $\mathrm{S}$ ), where $\mathrm{C}, \mathrm{N}, \mathrm{S}, \mathrm{F}$, and $\mathrm{M}$ indicate the control, no bedding chips stress, shaking stress, fasting stress, and movement restriction stress, respectively. Therefore, there was no case in which a significant difference existed between $\mathrm{C}$ and every stress condition.

These results suggest it is difficult to assign a particular single compound as a chemical marker of stressexposed mice. We then switched our strategy to consider a combination of multiple components relevant to various stresses.

Patterns of multiple odor compounds relevant to stress exposure

The analytical results in Table 3 were divided by the TL for the respective compounds listed in Table 2 to obtain the odor intensity and then digitized by the scale defined above. Table 4 summarizes the results. The concentrations of isobutyric acid, pentanal, dimethyl sulfide, dimethyl disulfide, and butanol were lower than the respective TLs under every condition. Therefore, these results were omitted from the table.

This table reflects the summation of qualitative effects of multiple compounds. The "qualitative" means whether the concentration is higher than the olfactory threshold or not. In addition, the influence of odor intensity is partially reflected by the digital scaling indicators. The pattern reflecting both influences suggests a feasible system for the detection of stress-exposed mice. The first step would be to analyze the concentration of these 12 compounds. The second step would be to determine the odor intensity. The final step would be to compare the pattern of the odor intensity scores.

If trimethylamine and hexanal are detected simultaneously, for example, the mouse might have been exposed to no bedding chips stress or fasting stress. If decanal and heptanal are detected simultaneously, the mouse was probably exposed to movement restriction stress. On the other hand, if acetaldehyde, 2,3-butanedione, and 3-methylbutanal are detected simultaneously, but no isobutanal, octanal, and nonanal is detected, the mouse was probably exposed to shaking stress.

Only a small amount of analytical data has been obtained to date, and therefore it is necessary to accumulate the results for various other conditions. However, the feasibility of this method has been well demonstrated. 
Table 4. Combination patterns of multiple odor compounds applicable to the distinctive detection of stress-exposed mice

\begin{tabular}{|c|c|c|c|c|c|c|c|}
\hline \multirow{2}{*}{\multicolumn{2}{|c|}{ Classification of detection pattern based on TL }} & \multirow[b]{2}{*}{ Compounds } & \multicolumn{5}{|c|}{ Breeding condition } \\
\hline & & & & No bedding & Shaking & Fasting & Movement \\
\hline \multirow{4}{*}{$\begin{array}{l}\text { Not detected } \\
\text { under control } \\
\text { condition }\end{array}$} & Detected under 1 stress condition & Decanal & 0 & 0 & 0 & 0 & 1 \\
\hline & & Heptanal & 0 & 0 & 0 & 0 & 1 \\
\hline & Detected under 2 stress conditions & Trimethylamine & 0 & 6 & 0 & 5 & 0 \\
\hline & & Hexanal & 0 & 1 & 0 & 1 & 0 \\
\hline \multirow{9}{*}{$\begin{array}{l}\text { Detected } \\
\text { under } \\
\text { control } \\
\text { condition }\end{array}$} & Detected under 2 stress conditions & Ethyl butyrate & 2 & 4 & 1 & 0 & 0 \\
\hline & & Isobutanal & 1 & 2 & 0 & 1 & 0 \\
\hline & Detected under 3 stress conditions & 2-Methylbutanal & 1 & 3 & 1 & 1 & 0 \\
\hline & & Octanal & 4 & 4 & 0 & 4 & 4 \\
\hline & & Nonanal & 2 & 2 & 0 & 2 & 2 \\
\hline & Detected under 4 stress condition & Acetaldehyde & 2 & 3 & 3 & 3 & 1 \\
\hline & & 2,3-Butanedione & 5 & 5 & 5 & 4 & 4 \\
\hline & & 3-Methylbutanal & 3 & 4 & 2 & 2 & 1 \\
\hline & Total score & & 20 & 34 & 12 & 23 & 14 \\
\hline
\end{tabular}

\section{Possible involvement of intestinal microbiota}

When a mouse is exposed to stress, its physiological condition will change, and its secretion of digestive enzymes will be modified. As a consequence, the digestion of food will be altered and cause a change in the waste products eventually voided. Changes to the feces are likely to change the odor. Digestion in the intestine is also facilitated by a number of anaerobic bacteria in the microbiota. The metabolism of these bacteria will be influenced by the environment in the intestine, i.e., by changes in $\mathrm{pH}$, redox potential, temperature, and digested substances; the bacteria will therefore be sensitive to the physiological condition of the mouse. The odor of the feces will also be modified by changes in the microbiota. The contribution of changes in the intestinal microbiota to fecal odor variation should be studied in detail in the future.

In summary, the odor of feces collected from mice was assessed by human olfaction and analyzed by GC/ MS. The odor intensity changed when the mice were exposed to stresses. The concentrations of dominant components were determined and then converted to digital scaling indicators based on their odor threshold levels. A set of 12 compounds was found to be useful for the recognition of stress-exposed mice.

\section{Acknowledgments}

This study was supported in part by the Strategic Re- search Promotion Program, Ministry of Education, Culture, Sports, Science and Technology, Japan, for research on "Development of Next-Generation Bioresource". This work was also funded by a collaborative research project: Dynamic Analysis of Metabolic Components in Experimental Animals in the Rearing Environment.

\section{References}

1. Bailey, M.T. and Coe, C.L. 1999. Maternal separation disrupts the integrity of the intestinal microflora in infant rhesus monkeys. Dev. Psychobiol. 35: 146-155. [Medline] [CrossRef]

2. Balcombe, J.P., Barnard, N.D., and Sandusky, C. 2004. Laboratory routines cause animal stress. Contemp. Top. Lab. Anim. Sci. 43: 42-51. [Medline]

3. Benno, Y., Endo, K., Mizutani, T., Namba, Y., Komori, T., and Mitsuoka, T. 1989. Comparison of fecal microflora of elderly persons in rural and urban areas of Japan. Appl. Environ. Microbiol. 55: 1100-1105. [Medline]

4. Berry, D.F., Madsen, E.L., and Bollag, J.M. 1987. Conversion of indole to oxindole under methanogenic conditions. Appl. Environ. Microbiol. 53: 180-182. [Medline]

5. Brown, M., Carbone, L., Conlee, K.M., Dawkins, M.S., Duncan, I.J., Fraser, D., Griffin, G., Hampshire, V.A., Lambert, L.A., Mench, J.A., Morton, D., Richmond, J., Rollin, B.E., Rowan, A.N., Stephens, M.L., and Würbel, H. 2006. Report of the working group on animal distress in the laboratory. Lab. Anim. (NY) 35: 26-30. [Medline] [CrossRef]

6. Dalton, P. 2003. Upper airway irritation, odor perception and health risk due to airborne chemicals. Toxicol. Lett. 140-141: 239-248. [Medline] [CrossRef]

7. Drozdowicz, C.K., Bowman, T.A., Webb, M.L., and Lang, 
C.M. 1990. Effect of in-house transport on murine plasma corticosterone concentration and blood lymphocyte populations. Am. J. Vet. Res. 51: 1841-1846. [Medline]

8. Forni, M. 2007. Laboratory animal science: a resource to improve the quality of science. Vet. Res. Commun. 31: 43-47. [Medline] [CrossRef]

9. Gärtner, K., Büttner, D., Döhler, K., Friedel, R., Lindena, J., and Trautschold, I. 1980. Stress response of rats to handling and experimental procedures. Lab. Anim. 14: 267-274. [Medline] [CrossRef]

10. Kurokawa, K., Itoh, T., Kuwahara, T., Oshima, K., Toh, H., Toyoda, A., Takami, H., Morita, H., Sharma, V.K., Srivastava, T.P., Taylor, T.D., Noguchi, H., Mori, H., Ogura, Y., Ehrlich, D.S., Itoh, K., Takagi, T., Sakaki, Y., Hayashi, T., and Hattori, M. 2007. Comparative metagenomics revealed commonly enriched gene sets in human gut microbiomes. DNA Res. 14: 169-181. [Medline] [CrossRef]

11. Macfarlane, S. and Macfarlane, G.T. 2003. Regulation of short-chain fatty acid production. Proc. Nutr. Soc. 62: 67-72. [Medline] [CrossRef]

12. Mitsuoka, T. and Hayakawa, K. 1973. The fecal flora in man. I. Composition of the fecal flora of various age groups. Zentralbl. Bakteriol. [Orig A] 223: 333-342. [Medline]

13. Rosenkranz, H.S. and Cunningham, A.R. 2003. Environmental odors and health hazards. Sci. Total Environ. 313: 15-24. [Medline] [CrossRef]

14. Schaefer, M.L., Wongravee, K., Holmboe, M.E., Heinrich, N.M., Dixon, S.J., Zeskind, J.E., Kulaga, H.M., Brereton, R.G., Reed, R.R., and Trevejo, J.M. 2010. Mouse urinary biomarkers provide signatures of maturation, diet, stress level, and diurnal rhythm. Chem. Senses 35: 459-471. [Medline] [CrossRef]

15. Shim, S.B., Lee, S.H., Kim, C.K., Kim, B.G., Kim, Y.K., Jee, S.W., Lee, S.H., Sin, J.S., Bae, C.J., Lee, B.C., Jang, M.K., Cho, J.S., Chae, K.R., and Hwang, D.Y. 2008. The effects of long-duration, low-temperature ground transportation on physiological and biochemical indicators of stress in mice. Lab. Anim. (NY) 37: 121-126. [Medline] [CrossRef]

16. Sullivan, F. and Leonardos, G. 1974. Determination of odor sources for control. Ann. N.Y. Acad. Sci. 237: 339-349. [Medline] [CrossRef] 